\title{
Genetic Parameters for Grain Yield and Nutritional Quality Traits in Foxtail Millet [Setaria italica (L.) Beauv.]
}

\author{
Md Ayesha ${ }^{1}$, D. Ratna Babu ${ }^{2}$, J. Dayal Prasad Babu ${ }^{3}$ and V. Srinivasa Rao ${ }^{4}$ \\ ${ }^{1}$ Department of Genetics and Plant Breeding, ${ }^{4}$ Department of Statistics and Mathematics, \\ Agricultural College, Bapatla, India \\ ${ }^{2}$ Department of Genetics and Plant Breeding, APGC, Lam. Guntur, India \\ ${ }^{3}$ Office of DSA, ANGRAU, Guntur, India \\ *Corresponding author
}

\begin{tabular}{|c|}
\hline Keywords \\
\hline $\begin{array}{l}\text { Foxtail millet, } \\
\text { Variability, } \\
\text { Heritability and } \\
\text { Genetic advance }\end{array}$ \\
\hline Article Info \\
\hline $\begin{array}{l}\text { Accepted: } \\
\text { 04 January } 2018 \\
\text { Available Online: } \\
\text { 10 February } 2019\end{array}$ \\
\hline
\end{tabular}

\section{Introduction}

Foxtail millet is largely self-pollinated, with cross pollination averaging about 4 per cent (Li et al., 1935). Foxtail millet ranks second in the world's total production of millets and is an important staple food for millions of people in Southern Europe and Asia (Marathee,
The present investigation was carried out to assess the nature and magnitude of genetic variability for yield and quality related traits in 50 genotypes of foxtail millet germplasm collections. The experiment was laid out in an Augmented Randomised Complete Block Design (ARCBD) at RARS, Lam, Guntur during Kharif, 2017-18. The analysis of variance revealed the presence of significant differences for most of the traits viz., days to $50 \%$ flowering, plant height, days to maturity, fat, carbohydrate, iron, phosphorus, calcium and grain yield per plant indicating that the collections under study were genetically diverse for most of the traits. Coefficient of variation studies indicated that the estimates of GCV were lesser than the corresponding PCV estimates for all the traits indicating the influence of environment on expression of these traits. High PCV and GCV were recorded for no. of productive tillers per plant, fat, iron, phosphorus, calcium and grain yield per plant, while days to $50 \%$ flowering recorded moderate PCV and GCV. The low GCV and PCV were recorded in plant height, days to maturity and carbohydrate. The grain yield and its components viz., days to $50 \%$ flowering, plant height, panicle length, protein, fat, iron, phosphorus and calcium exhibited high genetic advance as per cent of mean coupled with high estimates of heritability indicating that, there is predominance of additive gene action in controlling the inheritance of these traits and direct phenotypic selection would be effective for improvement of these traits. 
improvement. In any crop improvement programme, the knowledge of variability available is necessary. Yield is a complex character and is the product of the contribution of various yield components. Presence of a wider spectrum of variability will enhance the chances of selecting a desired genotype. Besides genetic variability, knowledge on heritability and genetic advance measures the relative degree to which a character is transmitted to progeny, thereby helps the breeder to employ a suitable breeding strategy to achieve the objective. Keeping the above points in view, the present investigation was carried out with the objective to find the extent of genetic variability, heritability and genetic advance.

\section{Materials and Methods}

The present investigation was carried out during kharif, 2017-18 at RARS, Lam, Guntur, Andhra Pradesh, which is located at $16.10^{\circ} \mathrm{N}$ latitude, $28.29^{\circ} \mathrm{E}$ longitude and 31.5 $\mathrm{m}$ altitude with 50 genotypes of foxtail millet germplasm [Setaria italica (L.) Beauv.] including checks. The trial was laid out in an Augmented Randomised Complete Block Design (Federer, 1956) with three checks viz., korra local, Prasad and Suryanandi in each block. Each genotype was grown in a single row of 4 m length with a spacing of $22.5 \mathrm{~cm}$ between the rows and $10 \mathrm{~cm}$ between the plants. Data were collected on five randomly selected plants per treatment for plant height, panicle length, no. of productive tillers per plant and grain yield per plant. However data on days to $50 \%$ flowering, days to maturity, test weight, protein, fat, carbohydrate, iron, phosphorus and were recorded on plot basis. Phenotypic and genotypic coefficients of variation were calculated according to the formula given by Burton (1952) and these PCV, GCV values were classified as described by Sivasubramanian and Menon (1973). Heritability $\left(\mathrm{h}^{2}\right)$ in the broad sense and narrow sense heritability was computed as suggested by Hanson et al., (1956) and heritability in the broad sense was categorised as per the classification given by Johnson et al., (1955). The range of genetic advance as per cent of mean was classified and calculated based on the formula given by Johnson et al., (1955). The estimates of mean, range, PCV, GCV, heritability $\left(\mathrm{h}_{\mathrm{bs}}^{2}\right)$ and genetic advance as per cent of mean (GAM) for foxtail millet genotypes are presented in Table 1.

\section{Results and Discussion}

The variation for number of days taken to $50 \%$ flowering ranged from 41 days (Ise-458) to 75 days (Ise-769) with a mean of 49.34 days. For plant height the range of variation varied from $89.08 \mathrm{~cm}$ (Ise-1026) to $168.08 \mathrm{~cm}$ (Ise-160) with a mean of $133.73 \mathrm{~cm}$. The trait panicle length has shown a variation ranging from $3.53 \mathrm{~cm}$ (Ise-785) to $18.53 \mathrm{~cm}$ (Ise-31) with a mean of $13.59 \mathrm{~cm}$. The variation for the character number of productive tillers per plant ranged from 1.52 (Ise-785) to 8.30 (Ise$1605)$ with a mean of 4.42 . Days to maturity is the another important character having a variation ranging from 72 days (Ise-1593) to 110 days (Ise-769) with a mean of 82.47days. Test weight on the other hand has shown a variation ranging from $1.13 \mathrm{~g}$ (Ise-1026) to $4.41 \mathrm{~g}$ (Ise-31, Ise-1881 and Ise-1892) with a mean of $2.72 \mathrm{~g}$. The protein content of the studied genotypes ranged from $6.01 \mathrm{~g}$ (Ise362 ) to $19.56 \mathrm{~g}$ (Ise-838) with a mean of 11.58 g. Similarly it was $1.81 \mathrm{~g}$ (Ise-995) to $5.62 \mathrm{~g}$ (Ise-1269) for fat with a mean of $3.52 \mathrm{~g}, 49.78$ $\mathrm{g}$ (Ise-1419) to $73.00 \mathrm{~g}$ (Ise-1605) for carbohydrate with a mean of around $64.54 \mathrm{~g}$, $1.22 \mathrm{mg}$ (Ise-840) to $27.73 \mathrm{mg}$ (Ise-1354) for iron with a mean of $12.54 \mathrm{mg}, 0.11 \mathrm{mg}$ (Ise1026) to $0.43 \mathrm{mg}$ (Ise-1780) for phosphorous with a mean of $0.28 \mathrm{mg}, 5.57 \mathrm{mg}$ (Ise-909) to $30.55 \mathrm{mg}$ (Ise-907 and Ise-1059) for calcium with a mean of $16.16 \mathrm{mg}$ and $3.77 \mathrm{~g}$ (Ise-785) to $39.83 \mathrm{~g}$ (Ise-1605) for grain yield per plant 
with a mean of around $15.18 \mathrm{~g}$. Yield is a complex character and is the product of the contribution of various yield components. Presence of a wider spectrum of variability will enhance the chances of selecting a desired genotype, as the success of any breeding programme depends upon the quantum of genetic variability present in the population.

For the trait days to $50 \%$ flowering the PCV (10.64) and GCV (10.48) estimates were moderate indicating moderate variation among genotypes studied and such estimates of PCV and GCV were earlier reported by Nirmalakumari et al., (2008), Tyagi et al., (2011) and Brunda et al., (2014). The estimates of PCV (9.91) and GCV (9.87) were low for plant height indicating less variation among the genotypes studied. Similar results were reported by Brunda et al., (2014) and Jyothsna et al., (2016). The estimates of PCV (22.28) and GCV (19.69) were high and moderate for the character panicle length and the difference between PCV and GCV value is less indicating that there is little role of environmental component in the observed variation. Similar results for high $\mathrm{PCV}$ and moderate GCV were earlier reported by Prasad et al., (1985). For the trait number of productive tillers per plant, the estimates of PCV (36.36) and GCV (22.03) were high. The difference between PCV and GCV value is more which indicates that there is high influence of environment in the observed variation. Similar results of high PCV and GCV were reported by Nirmalakumari et al., (2008), Nirmalakumari and Vetrivethan (2010), Prasanna et al., (2013), Yogeesh et al., (2015), Jyothsna et al., (2016), Ashok et al., (2016) and Kavya et al., (2017). The estimates of PCV (7.30) and GCV (7.12) were low for days to maturity and the difference between PCV and GCV value is less which indicates that there is little role of environmental component in the observed variation. These results are in agreement with Nirmalakumari et al., (2008), Nirmalakumari and Vetrivethan (2010), Jyothsna et al., (2016) and Ashok et al., (2016). For the character test weight the estimate of PCV (23.08) was high and GCV (14.44) was moderate. Similar results for high PCV were reported by Sirisha et al., (2009), and Kavya et al., (2017). While moderate GCV was reported by Nirmalakumari et al., (2008). High PCV (21.76) and moderate GCV (19.35) were recorded for the trait seed protein. Similar results of high PCV were reported by Rani (2014) in finger millet, while Sirisha et al., (2009), Smita et al., (2016) and Kavya et al., (2017) reported moderate GCV for this trait in foxtail millet.

High PCV (26.19) and GCV (24.11) were recorded for seed fat and it was in line with the results of Govindaraj et al., (2011) in pearl millet. The estimates of PCV (7.03) and GCV (6.89) were low for carbohydrate indicating less variation among genotypes studied and these findings are in conformity with the results of Kavya et al., (2017). The estimates of PCV (52.15) and GCV (51.83) were high for the character iron and these findings are in conformity with the results of Govindaraj et al., (2011) in pearl millet and Smita et al., (2016) in foxtail millet. For phosphorous content the estimates of PCV (26.98) and GCV (26.64) were high indicating large variation among genotypes studied. These findings are in contrary to the results of Govindaraj et al., (2011) in pearl millet where he obtained low PCV and GCV. High PCV (35.97) and GCV (35.47) were recorded for the trait calcium indicating large variation among genotypes studied and these findings are in conformity with the results of Prasanna et al., (2013). From the above studied PCV and GCV values we can infer that the genotypic coefficients of variation for all the characters studied were lesser than the phenotypic coefficients of variation indicating the influence of environment on expression of these traits. 
Table.1 Estimates of variability, heritability and genetic advance as per cent of mean for grain yield and quality components in foxtail millet [Setaria italica (L.) Beauv.]

\begin{tabular}{|c|c|c|c|c|c|c|c|c|}
\hline \multirow{2}{*}{$\begin{array}{l}\text { S. } \\
\text { No. }\end{array}$} & \multirow[t]{2}{*}{ Character } & \multirow[t]{2}{*}{ Mean } & \multicolumn{2}{|c|}{ Range } & \multicolumn{2}{|c|}{ Coefficient of variation } & \multirow{2}{*}{$\begin{array}{c}\text { Heritability } \\
\text { (broad sense) } \\
(\%)\end{array}$} & \multirow{2}{*}{$\begin{array}{c}\text { Genetic } \\
\text { advance as \% } \\
\text { of mean }\end{array}$} \\
\hline & & & Minimum & Maximum & PCV (\%) & GCV (\%) & & \\
\hline 1 & Days to $50 \%$ flowering & 49.34 & 41.00 & 75.00 & 10.64 & 10.48 & 96.90 & 21.25 \\
\hline 2 & Plant height $(\mathrm{cm})$ & 133.73 & 89.08 & 168.08 & 9.91 & 9.87 & 99.10 & 20.24 \\
\hline 3 & Panicle length $(\mathrm{cm})$ & 13.59 & 3.53 & 18.53 & 22.28 & 19.69 & 78.10 & 35.86 \\
\hline 4 & No. of productive tillers/plant & 4.42 & 0.52 & 8.30 & 36.36 & 22.03 & 36.70 & 27.51 \\
\hline 5 & Days to maturity & 82.47 & 72.00 & 110.00 & 7.30 & 7.12 & 95.40 & 14.33 \\
\hline 6 & Test wt (g) & 2.72 & 1.13 & 4.41 & 23.08 & 14.44 & 39.20 & 18.62 \\
\hline 7 & Protein (g/100g) & 11.58 & 6.01 & 19.56 & 21.76 & 19.35 & 79.10 & 35.44 \\
\hline 8 & Fat $(g / 100 g)$ & 3.52 & 1.81 & 5.62 & 26.19 & 24.11 & 84.80 & 45.74 \\
\hline 9 & Carbohydrate $(\mathrm{g} / 100 \mathrm{~g})$ & 64.54 & 49.78 & 73.00 & 7.03 & 6.89 & 96.20 & 13.93 \\
\hline 10 & Iron $(\mathrm{mg} / 100 \mathrm{~g})$ & 12.54 & 1.22 & 27.73 & 52.15 & 51.83 & 83.34 & 89.00 \\
\hline 11 & Phosphorus (g/100g) & 0.28 & 0.11 & 0.43 & 26.98 & 26.64 & 97.50 & 54.19 \\
\hline 12 & Calcium (mg/100g) & 16.16 & 5.57 & 30.55 & 35.97 & 35.47 & 97.20 & 72.05 \\
\hline 13 & Grain yield/plant $(\mathrm{g})$ & 15.18 & 3.77 & 39.83 & 44.95 & 44.00 & 95.80 & 88.73 \\
\hline
\end{tabular}

PCV = Phenotypic coefficient of variation $\mathrm{GCV}=$ Genotypic coefficient of variation 
Consistency in the performance of selection in succeeding generations depends on the magnitude of heritable variation present in relation to observed variation. The estimates of heritability revealed that except for the traits number of productive tillers per plant (36.70) and test weight (39.20) all the remaining traits were found to have high magnitude of heritability. Heritability estimates alone cannot give a better idea in selecting suitable breeding method. So in order to fulfil the requirement we have also estimated genetic advance in addition to the heritability. Heritability estimates along with genetic advance are more helpful in predicting the gain under selection than heritability estimates alone and these will also give a better picture for having an idea of gene action involved. However, it is not necessary that a character showing high heritability will always exhibit high genetic advance. Of the thirteen characters concerned, high heritability coupled with high genetic advance was noted for days to $50 \%$ flowering, plant height, panicle length, protein, fat, iron, phosphorous, calcium and grain yield per plant indicating the predominance of additive gene action, there by direct selection will be effective to obtain the desired results. The results were in accordance with Sirisha et al., (2009), Nirmalakumari and Vetrivethan (2010), Tyagi et al., (2011), Govindaraj et al., (2011) in pearl millet, Brunda et al., (2014), Yogeesh et al., (2015), Ashok et al., (2016), Smita et al., (2016) and Kavya et al., (2017). High heritability coupled with moderate genetic advance were recorded for days to maturity and carbohydrate indicating the preponderance of both additive and non additive gene action indicating that simple selection will not be rewarding in improving this trait. Similar results were earlier reported by Nirmalakumari et al., (2008), Nirmalakumari and Vetrivethan (2010) and Jyothsna et al., (2016). Moderate heritability coupled with moderate genetic advance was recorded for the trait test weight indicating that there is involvement of both additive and non-additive gene actions which may not be exploited through simple selection procedures. However different results of high heritability and moderate genetic advance as per mean were indicated by Prasad et al., (1985). Moderate heritability coupled with high genetic advance was recorded for number of productive tillers per plant indicating the preponderance of both additive and non-additive gene action and hence simple selection may not be rewarding. These findings are in accordance with those of Jyothsna et al., (2016).

\section{References}

Ashok, S., Patro, T.S.S.K., Jyothsna, S. and Divya, M. 2016. Studies on genetic parameters, correlation and path analysis for grain yield and its components in foxtail millet (Setaria italica). Progressive Research. 11(3): 300-303.

Brunda, S.M., Kamatkar, M.Y., Hundekar, R. and Naveenkumar, K.L. 2014. Studies on genetic variability, heritability and genetic advance in foxtail millet in both rainy and post rainy season. IOSR-Journal of Agriculture and Veterinary Science. 7(2): 34-37.

Burton, G.W. 1952. Quantitative inheritance in grasses. Proceedings of the $6^{\text {th }}$ International Grassland Congress. 277-283.

Federer, W.T. 1956. Augmented designs. Hawaiian Planter's Record. 55: 191-208.

Govindaraj, M., Selvi, B., Rajarathinam, S. and Sumathi, P. 2011. Genetic variability and heritability of grain yield components and grain mineral concentration in India's' pearl millet [Pennisetum glaucum (L) R. Br.] accessions. African Journal of Food, Agriculture, Nutrition and Development. 11(3): 4758-4771.

Hanson, C.H., Robinson, H.F. and Comstock, R.E. 1956. Biometrical studies of yield in segregating populations of Korean 
Lespedeza. Agronomy Journal. 48(6): 268272.

Johnson, H.W., Robinson, H.F. and Comstock, R.E. 1955. Estimates of genetic and environmental variability in soyabean. Agronomy Journal. 47: 314-318.

Jyothsna, S., Patro, T.S.S.K., Rani, Y.S., Ashok, S., Neeraja, B. and Triveni, U. 2016. Studies on genetic variability and interrelationship between grain yield and its components in foxtail millet (Setaria italica). International Journal of Agriculture Sciences. 8(5): 1015-1017.

Kavya, P., Sujatha, M., Pandravada, S.R. and Hymavathi, T.V. 2017. Variability Studies in foxtail millet [Setaria italica (L.) P. Beauv.]. International Journal of Current Microbiology and Applied Sciences. 6(9): 955-960.

Li, H., Meng, W.J. and Liu, T.M. 1935. Problems in the breeding of millet [Setaria italica (L.) Beauv.]. Journal of American Society of Agronomy. 27: 426-438.

Marathee, J.P. 1993. Structure and characteristics of the world millet economy. Advances in small millets (Riley $\mathrm{KW}$, Gupta SC, Seetharam A and Mushonga JN, eds.). New Delhi, India: Oxford \& IBH. 159-178.

Nirmalakumari, A., and Vetriventhan, M. 2010. Characterization of foxtail millet germplasm collections for yield contributing traits. Electronic Journal of Plant Breeding. 1(2): 140-147.

Nirmalakumari, A., Ganapathy, S. and Murugan, R. 2008. Studies on variability and descriptive statistics in foxtail millet [Setaria italica (L.) Beauv.] germplasm. Crop Research. 35(1\&2): 80-82.

Prasad, G.P., Rao, N.M. and Anjanappa, M. 1985. Genetic variability in setaria (Setaria italica (L.) Beauv.). The Andhra Agricultural Journal. 32(1): 34-36.

Prasanna, P.L., Murthy, J.S.V.S., Kumar, P.V.R. and Rao, S.V. 2013. Nature of gene action for yield and yield components in exotic genotypes of Italian millet. [Setaria italica (L.) Beauv.]. Journal of Plant Breeding and Crop Science. 5(5): 80-84.

Rani, A.J. 2014. Study of genetic divergence for grain yield and yield components in finger millet [Eleucine coracana (L.) Gaertn.]. M.Sc.(Ag.) thesis, Acharya N. G. Ranga Agricultural University, Hyderabad.

Sirisha, A.B.M., Rao, C.P., Kumar, P.V.R. and Rao, V.S. 2009. Variability, character association and path coefficient analysis in italian millet [Setaria italica (L.) Beauv.]. The Andhra Agricultural Journal. 56(4): 441-446.

Sivasubramanian, P., and Menon, P.M. 1973. Inheritance of short stature in rice. Madras Agricultural Journal. 60: 1129-1133.

Smita, S., Patil, J.V., Sunil, G. and Ganapathy, K.N. 2016. Genetic variability and association analysis for grain yield and nutritional quality in foxtail millet. International Journal of Bio-Resource and Stress Management. 7(6): 1239-1243.

Tyagi, V., Ramesh, B., Kumar, D. and Sukrampal. 2011. Genetic architecture of yield contributing traits in foxtail millet (Setaria italica). Current Advances in Agricultural Sciences. 3(1): 29-32.

Yogeesh, L.N., Shankar, K.A., Prashant, S.M. and Lokesh, G.Y. 2015. Genetic variation and morphological diversity in foxtail millet. International Journal of Science, Environment and Technology. 4(6): 14961502.

\section{How to cite this article:}

Md Ayesha, D. Ratna Babu, J. Dayal Prasad Babu and Srinivasa Rao, V. 2019. Genetic Parameters for Grain Yield and Nutritional Quality Traits in Foxtail Millet [Setaria italica (L.) Beauv.]. Int.J.Curr.Microbiol.App.Sci. 8(02): 4-9.

doi: https://doi.org/10.20546/ijcmas.2019.802.002 